\title{
The Administration of Bona Vacantia (Ownerless Property) in West Malaysia: A Comparative Analysis
}

Rahmawati Mohd Yusoff, Akmal Hidayah Halim, Wan Amir Azlan, Azhani Arshad, Alizah Ali, Noraini Ismail, Ahmad Faiz Ghazali, Zuramaznum Sainan

To Link this Article: http://dx.doi.org/10.6007/IJARBSS/v11-i5/9824 DOI:10.6007/IJARBSS/v11-i5/9824

Received: 08 April 2021, Revised: 30 April 2021, Accepted: 17 May 2021

Published Online: 28 May 2021

In-Text Citation: (Yusoff et al., 2021)

To Cite this Article: Yusoff, R. M., Halim, A. H., Azlan, W. A., Arshad, A., Ali, A., Ismail, N., Ghazali, A. F., \& Sainan, Z. (2021). The Administration of Bona Vacantia (Ownerless Property) in West Malaysia: A Comparative Analysis. International Journal of Academic Research in Business and Social Sciences, 11(5), 586-597.

\section{Copyright: @ 2021 The Author(s)}

Published by Human Resource Management Academic Research Society (www.hrmars.com)

This article is published under the Creative Commons Attribution (CC BY 4.0) license. Anyone may reproduce, distribute, translate and create derivative works of this article (for both commercial and non-commercial purposes), subject to full attribution to the original publication and authors. The full terms of this license may be seen at: http://creativecommons.org/licences/by/4.0/legalcode

Vol. 11, No. 5, 2021, Pg. 586 - 597

Full Terms \& Conditions of access and use can be found at http://hrmars.com/index.php/pages/detail/publication-ethics 


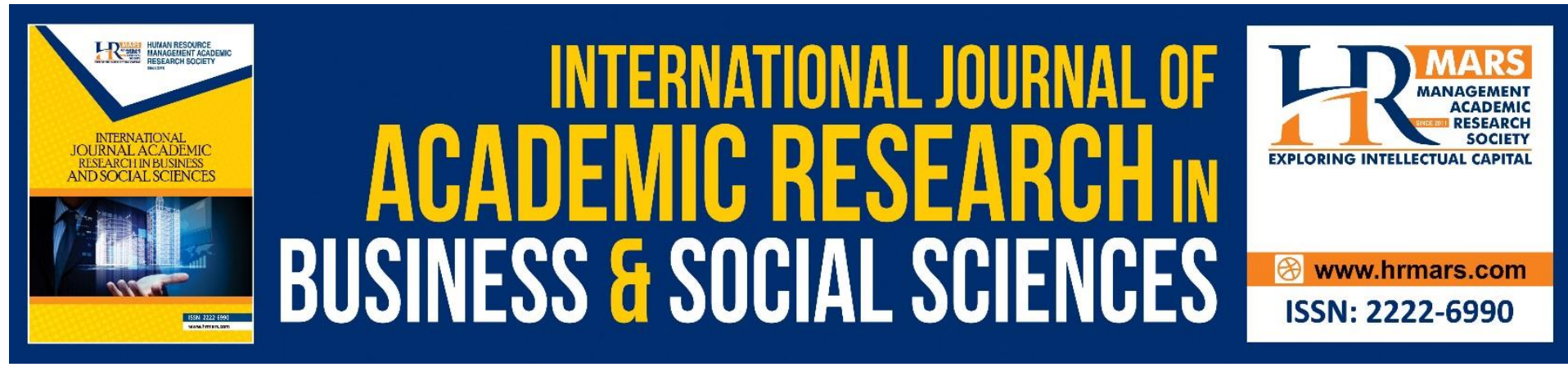

\title{
The Administration of Bona Vacantia (Ownerless Property) in West Malaysia: A Comparative Analysis
}

Rahmawati Mohd Yusoff, ${ }^{1}$ Akmal Hidayah Halim, ${ }^{2}$ Wan Amir Azlan, ${ }^{3}$ Azhani Arshad, ${ }^{4}$ Alizah Ali, ${ }^{5}$ Noraini Ismail, ${ }^{6}$ Ahmad Faiz Ghazali, ${ }^{7}$ Zuramaznum Sainan ${ }^{8}$

${ }^{1}$ Senior Lecturer, Universiti Teknologi Mara (UiTM), Cawangan Johor, Kampus Segamat, 85000 Segamat, Johor, ${ }^{2}$ Associate Professor, Ahmad Ibrahim Kuliyyah of Laws, International Islamic University Malaysia, P.O. Box 10, 50728 Kuala Lumpur, ${ }^{3}$ Senior Lecturer, Universiti Teknologi Mara (UiTM), Cawangan Johor, Kampus Segamat, 85000 Segamat, Johor, ${ }^{4}$ Senior Lecturer, Universiti Teknologi Mara (UiTM), Shah Alam, 40450 Selangor, ${ }^{5}$ Senior Lecturer,

Universiti Teknologi Mara (UiTM), Cawangan Johor, Kampus Segamat, 85000 Segamat, Johor, ${ }^{6}$ Senior Lecturer, Universiti Teknologi Mara (UiTM), Cawangan Johor, Kampus Segamat, 85000 Segamat, Johor, ${ }^{7}$ Senior Lecturer, Universiti Teknologi Mara (UiTM), Cawangan Johor, Kampus Segamat, 85000 Segamat, Johor, ${ }^{8}$ Senior Lecturer, Universiti Teknologi Mara (UiTM), Cawangan Johor, Kampus Segamat, 85000 Segamat, Johor.

Email: rahmawatimy@uitm.edu.my, akmalh@iium.edu.my,wamirazlan@uitm.edu.my, azhani_arshad@uitm.edu.my, aliza941@uitm.edu.my,norai257@uitm.edu.my,

faizghazali@uitm.edu.my, zuram778@uitm.edu.my

\begin{abstract}
The terms bona vacantia and ownerless property have been used interchangeably which refers to assets or goods that do not have an owner. Every year, the number of unclaimed estates in Malaysia is constantly rising and the call for a better regulation and management of bona vacantia estates has never been more important. This paper aims to enhance the administration of bona vacantia in west Malaysia by referring Singapore and the United Kingdom in light of potential for cross-jurisdictional use of the framework. The doctrinal analysis was adopted by analysing the current primary and secondary materials which includes statutory provisions, journal articles, books and other legal and non-legal literatures. The study finds key features of each of the jurisdiction as well as important similarities and differences that could be useful to be implemented in Malaysia. As a recommendation, Malaysian authority may take advantage on interest payment for any claim made by the beneficiary up to certain years in order to encourage beneficiaries to cooperate together to claim the estates in question immediately. Further, by introducing Unclaimed Estates Websites may be able to provide accessibility of information and platform for long lost beneficiaries or relatives to meet up virtually.
\end{abstract}


Keywords: Bona vacantia, Baitulmal, Government, Bona Vacantia Division, Governement Legal Department.

\section{Introduction}

Bona vacantia is a Latin term that refers to assets or goods that do not have an owner (Halim et al, 2019). According to Kuek \& Tay (2013), the term has been used interchangeably with ownerless property which carries the same message when it comes to a legal term. It worth noting that the administration and management of bona vacantia varies depending on the state's jurisdiction. With the aim of enhancing the administration of bona vacantia in Malaysia, this paper first analyses the existing management of bona vacantia in Malaysia. Next, the same will be discussed and scrutinised with references to Singapore and United Kingdom. This article will later highlights the similarities and differences of the administration and regulation of bona vacantia in three (3) different jurisdictions. These details were analysed by legal interpretation and comparative assessment (Haniff, Hakimah \& Ismail, 2019).

\section{The Administration of Bona Vacantia in Malaysia}

The number of unclaimed estates in Malaysia is constantly rising and among factor that contributes it is due to the increasing number of legal heirs who found it difficult to cooperate among them in order to acquire the transfer of wealth and develop it diligently (Yusoff, 2019). Aziz (2016) in his report stated that as of 2016, the total amount of unclaimed inheritance estate in Malaysia is worth approximately RM60 billion. In additions, Halim, Noor \& Arshad (2018) stated that there are several types of unclaimed estates namely unclaimed money, undistributed fund and bona vacantia which remain hitherto uncertain and not specifically identified, thus leading to the peculiarities of unclaimed estates in the administration of the deceased's estate in Malaysia. To add insult to the injury, the existence of various laws that governs different types of unclaimed estates has led to the distinctive methods in the administration and management of such estates. In other words, more properties will be left unattended and the call for a better regulation and management of bona vacantia estates has never been more important (Halim \& Yusoff, 2019).

In west Malaysia, the dual system has been used in estate matters, depending on the deceased's religion. As a consequence, separate sets of personal laws have authority over the administration of bona vacantia. The bona vacantia estates, whether immovable or movable, are reverted to Baitulmal for Muslims. For Non-Muslims on the other hand, have their movable property vested in the Federal Consolidated Fund or known as Yang Di-Pertuan Agong $^{1}$ (YDPA) Fund, while their immovable property is accrued to the State Authority.

For muslim, several statutes govern the matter of bona vacantia which are Federal Constitution, Small Estates (Distribution) Act 1955 and National Land Code 1965. Pursuant to Item 1, List II (State List), Ninth Schedule of Malaysia Federal Constitution, the Islamic law only applies to Muslim personal laws which includes succession, intestate, testate and Baitulmal. ${ }^{2}$

\footnotetext{
${ }^{1}$ Supreme Lord of Malaysia

${ }^{2}$ According to Nor (2015), baitulmal is a store treasury or property house which manages all properties and financial resources of Muslims community.
} 
Next, by virtue of Section 351 of National Land Code 1965, the alienated land shall be reverted to and vested in the State Authority under Section 351 of the National Land Code of 1965 , which specifies the death of a proprietor without successor.

1) "Where any Land Administrator-

(a) receives evidence from which he is satisfied that the proprietor of any alienated land (in this section referred to as the original proprietor) has died, and

(b) is also satisfied that no petition has been filed for a grant of representation to the estate of the original proprietor, and that no petition for the distribution of that estate has been lodged under the Small Estates (Distribution) Act 1955, he may make, or cause to be made, an endorsement to that effect on the register document of title to the land.

(3) As soon as may be after the making of any such endorsement, the Land Administrator shall, by notice in the Gazette in Form 23A, declare-

(a) that the original proprietor of the land appears to have died without successors; and

(b) that the land will revert to the State Authority, or in the case of an undivided share in land, will become vested in the State Authority at the end of the period of one year beginning with the date on which the notice is published unless by that time one of the following requirements has been fulfilled.

(6) If none of the requirements specified in any such notice has been fulfilled by the end of the said period or, as the case may be, the period as so extended, the land to which the notice relates shall thereupon (but subject always to the provisions of any law for the time being in force relating to bait-ul-mal) revert to the State Authority as if it had been forfeited pursuant to the provisions of Part Eight, or become vested in the State Authority, as the case may be."

The Baitulmal's right to the deceased's estate has also been recognised by statute in the proviso to Section 13(1) of the Small Estates (Distribution) Act 1955. The section states that:

"Provided that where there is in force any written law relating to Baitulmal the Collector shall before distributing any part of the estate of a deceased Muslim satisfy himself that any share of the estate which is due to the baitulmal has been duly paid or proper provision made for the payment thereof."

In Islamic law, the law of faraid states that there are three (3) situations where Baitulmal will inherit the estate of a deceased. First, when a Muslim who has no relatives to inherit his estates (Al-Zuhayli \& Wahbah ibn Mustafa, nd). Second, when there is no surviving heir to take the balance (asabah) of the deceased's land. Third, according to Tyabji (1940), the legitimate heir may exist but is barred from inheriting the land. This kind of situation happen when the heir belongs to the category of zawi al-arham (relatives), the heir follows a different faith or the heir caused the death of the deceased (Salim, 2012).

The administration of bona vacantia for non-Muslims, on the other hand, anticipates any custom that will divide and subsist the remainder of the estate according to the 
Distribution Act 1958 (Sihombing, 1981). By virtue of Section 4 of the Distribution Act 1958, the provision provides:

4. (1) "The distribution of the movable property of a person deceased shall be regulated by the law of the country in which he was domiciled at the time of his death.

(2) The distribution of the immovable property of a person deceased intestate shall be regulated by this Act wherever he may have been domiciled at the time of his death."

In addition, Section 6 of the Distribution Act 1958 lays out the scheme for intestacy distribution. Section 6(1) of the Distribution Act 1958 provides as follows:

(j) "In default of any person taking an absolute interest under the foregoing provisions the Government shall be entitled to the whole of the estate except insofar as the same consists of land."

In addition, Section 24 of the Civil Law Act of 1956 contains a provision for nonMuslims' bona vacantia. The section said:

24. "When a right to the personal estate of any person who dies intestate without next of kin has accrued to the Government, the personal estate or the proceeds thereof shall form part of the Consolidated Fund and shall be appropriated as part of the Fund to such public purposes as the Yang di-Pertuan Agong from time to time thinks proper and directs:

Provided that the Yang di-Pertuan Agong may by warrant order the transfer of the whole or any part of such personal estate or the proceeds thereof to any person who shall establish to the satisfaction of the Yang di-Pertuan Agong any equitable or moral claim thereto."

Notably, the Federal Constitution stipulates on the Federal Consolidated Fund as below:

97. (1) "All revenues and moneys howsoever raised or received by the Federation shall, subject to the provisions of this Constitution and of federal law, be paid into and form one fund, to be known as the Federal Consolidated Fund.

(2) All revenues and moneys howsoever raised or received by a State shall, subject to Clause (3) and to any law, be paid into and form one fund, to be known as the Consolidated Fund of that State.

(3) If in accordance with State law or in respect of the Federal Territories of Kuala Lumpur, Labuan and Putrajaya, in accordance with federal law any Zakat, Fitrah, Baitulmal, or similar Islamic religious revenue is raised, it shall be paid into a separate fund and shall not be paid out except under the authority of State law or federal law, as the case may be.

(4) Unless the context otherwise requires, any reference in this Constitution to the Consolidated Fund shall be construed as a reference to the Federal Consolidated Fund."

Furthermore, bona vacantia applies when a deceased person who is entitled to a pecuniary legacy under a will has died without a next of kin, or when there is intestacy as to the residuary estate and the testator has no next of kin, or where there is intestacy as to the residuary estate because the will does not have a residuary clause and the testator has no relatives (Halim, Noor \& Arshad, 2018). 


\section{The Administration of bona vacantia in Singapore}

In Singapore, the administration of bona vacantia is regulated by a different set of personal laws. By virtue of Section 27 of the Civil Law Act (Cap. 43), bona vacantia of the estates of non-Muslims are accrued to the Government. The section provides as follows:

1) "This section applies -

a) where a right to the estate of any person who dies (whether before, on, or after the date of commencement of Section 2 of the Civil Law [Amendment] Act 2012) intestate without next of kin has accrued to the Government; or

b) where a right to the property of any person who dies (whether before, on, or after the date of commencement of Section 2 of the Civil Law [Amendment] Act 2012) has accrued to the Government as a result of disposal under such written law as the Minister may, by order, publish in the Gazette, prescribed for the purposes of this section.

2) Where a right to any estate or property upon the death of a person as mentioned in Subsection (1) has accrued to the Government, such estate, property, or part thereof that is not land, or where such estate or property, or part thereof is land and that land is sold, its proceeds, shall form part of the Consolidated Fund."

In exercise of the powers conferred by Section 27(1)(b) of the Civil Law Act, the Minister for Law makes the Order cited as the Civil Law (Bona Vacantia Laws) Order 2013. This order states the following prescribed laws for properties which may accrue bona vacantia, namely Sections 24(3A) and 25 of the Central Provident Fund Act (Cap. 36); Section 6 of the Child Development Co-Savings Act (Cap. 38A); and Sections 16 and 16H of the Education Endowment and Savings Schemes Act (Cap. 87A).

The provision for bona vacantia estates can also be found in Section 7 of the Intestate Succession Act (Cap. 146) which outlines that "in the default of distribution under Rules 1 to 8 of this section, the Government shall be entitled to the whole of the estate." ${ }^{3}$ However, by

${ }^{3}$ Section 7, Intestate Succession Act (Cap. 146):

In effecting such distribution, the following rules shall be observed:

Rule 1: "If an intestate dies leaving a surviving spouse, no issue, and no parent, the spouse shall be entitled to the whole of the estate."

Rule 2: "If an intestate dies leaving a surviving spouse and issue, the spouse shall be entitled to one-half of the estate."

Rule 3: "Subject to the rights of the surviving spouse, if any, the estate (both as to the undistributed portion and the reversionary interest) of an intestate who leaves issue shall be distributed by equal portions per stirpes to and amongst the children of the person dying intestate and such persons as legally representing those children, in case any of those children be then dead."

Proviso No. (1): "The persons who legally represent the children of an intestate are their descendants and not their next of kin."

Proviso No. (2): "Descendants of the intestate to the remotest degree stand in the place of their parent or other ancestor, and take according to their stocks the share which he or she would have taken." 
virtue of Section $4(1 \mathrm{~A})(\mathrm{d})$ of the Public Trustee Act (Cap. 260), "the Public Trustee may undertake such functions and duties related to bona vacantia in the event of the death of natural persons, as assigned by the Minister." The Public Trustee, who conducts business at the Public Trustee's Office under the Ministry of Law, is considered to hold the bona vacantia estates.

In contrast, the estates of the Muslims will be paid to Baitulmal, in accordance with the Islamic inheritance laws. Notably, Section 27(6) of Civil Law Act (Cap. 43) states that "no clause in this section could affect the disposal of any property according to the Islamic law." Similarly, Section 111 of the Administration of Muslim Law Act (Cap. 3) outlines that "the distribution of Muslim estate needs to be according to the Islamic law."

\section{The Administration of bona vacantia in United Kingdom}

By virtue of Section 46 of Administration of Estates Act 1925, "bona vacantia estates shall belong to the Crown." The section provides that "in default of any person taking an absolute interest under the foregoing provisions of Subsection 46(1)(i)-(v) of the Act, the residuary estate of the intestate shall belong to the Crown, or to the Duchy of Lancaster or to the Duke of Cornwall for the time being, as the case may be, as bona vacantia, and in lieu of any right to escheat. The Crown or the said Duchy or the said Duke may (without prejudice to the powers reserved by Section Nine of the Civil List Act 1910, or any other powers), out of the whole or any part of the property devolving on them respectively, provide, in accordance with the existing practice, for dependants, whether kindred or not, of the intestate, and other persons for whom the intestate might reasonably have been expected to make provision."

In particular, under company law, the rights and properties of a company which has been dissolved are bona vacantia. This includes the right to a tax refund from the Government Legal Department(Gov.uk, 2020) and Section 1012 of Companies Act (2006) provides as follows:

1) "When a company is dissolved, all properties and rights whatsoever vested in or held on trust for the company immediately before its dissolution (including

Rule 4: "If an intestate dies leaving a surviving spouse and no issue but a parent or parents, the spouse shall be entitled to one-half of the estate and the parent or parents to the other half of the estate."

Rule 5: "If there are no descendants, the parent or parents of the intestate shall take the estate, in equal portions if there are 2 parents, subject to the rights of the surviving spouse (if any) as provided in Rule 4."

Rule 6: "If there are no surviving spouse, descendants, or parents, the brothers and sisters and children of the deceased brothers or sisters of the intestate shall share the estate in equal portions between the brothers and sisters, and the children of any deceased brothers or sisters shall take according to their stocks the share which the deceased brothers or sisters would have taken."

Rule 7: "If there are no surviving spouse, descendants, parents, brothers, and sisters, or children of such brothers and sisters, but grandparents of the intestate, the grandparents shall take the whole of the estate in equal portions."

Rule 8: "If there are no surviving spouse, descendants, parents, brothers, and sisters, or their children or grandparents, but uncles and aunts of the intestate, the uncles and aunts shall take the whole of the estate in equal portions."

Rule 9: "In default of distribution under Rules 1 to 8 , the Government shall be entitled to the whole of the estate." 
leasehold property, but not including property held by the company on trust for another person) are deemed to be bona vacantia and-

a) accordingly belong to the Crown, or to the Duchy of Lancaster or to the Duke of Cornwall for the time being (as the case may be), and

b) vest and may be dealt with in the same manner as other bona vacantia accruing to the Crown, to the Duchy of Lancaster, or to the Duke of Cornwall."

When there are no known heirs to an estate, the Government Legal Department's Bona Vacantia Division (BVD) keeps the estate in trust and lists it on the bona vacantia list in the hopes that an heir or heirs may come forward to claim it. ${ }^{4}$ The BVD works for the Crown to manage the estates of people who die intestate and have no known heirs, as well as collect the properties of dissolved companies and other ownerless assets in the UK(Gov.uk, nd (a)). Notably, the Government Legal Department, is a non-ministerial department that serves as the government's primary legal advisor(Gov.uk, nd (b)). Meanwhile, the Crown Estate is an autonomous commercial business that operates with HM Treasury and is incorporated as a statutory corporation under the Crown Estate Act 1961 (Gov.uk, nd (c)).

Apart from that, the Unclaimed Estates websites are extremely useful in assisting legitimate heirs in inheriting estates rather than allowing them to go unclaimed for a long time or being transferred to the Crown by the Government Legal Department or other governments or authorities in other jurisdictions. (Unclaimed estates, 2021). In general, BVD will consider claims within 12 years of the completion of the estate administration, and interest will be charged on the money kept. If a claim is made after the 12-year limit has expired, BVD can accept fully reported claims up to 30 years from the date of death, with no payment of interest on the money kept. Any petition filed with the BVD after the 30-year period has passed will be ignored, and the estate will revert to the Crown (Gov.uk, nd (d)).

\section{A Comparative Analysis of the Administration of bona vacantia in Malaysia, Singapore and United Kingdom}

The administration of bona vacantia in Malaysia and Singapore is fairly similar as the bona vacantia estates in both countries are governed by a different set of personal laws. In Malaysia, Federal Constitution, National Land Code 1965 and Small Estates (Distribution) Act 1955 govern bona vacantia for Muslims and will devolve upon the Baitulmal. Whereas Civil Law Act 1956, Distribution Act 1958, National Land Code 1965 and Federal Constitution govern non-Muslims' estates. Particularly, their movable properties are reverted to the YDPA fund, while the immovable properties will accrue to the State Authority.

In Singapore, the personal law of the deceased governs the bona vacantia estates. However, Civil Law (Bona Vacantia Laws) Order 2013 made under the powers conferred by Section 27(1)(b) of the Civil Law Act (Cap. 43) provides several prescribed laws under which property may accrue as bona vacantia, namely Sections 24(3A) and 25 of the Central Provident Fund Act (Cap. 36); Section 6 of the Child Development Co-Savings Act (Cap. 38A); and Sections 16 and $16 \mathrm{H}$ of the Education Endowment and Savings Schemes Act (Cap. 87A). The bona vacantia estates are governed by Islamic law for Muslims under the Administration of Muslim Law Act (Cap. 3), which concluded that Baitulmal would inherit the estate. Meanwhile, the Civil Law Act governs non-Muslims' bona vacantia (Cap. 43) and the Intestate

\footnotetext{
${ }^{4}$ Unclaimed Estates, accessed January 21, 2021, http://www.unclaimed-estates.org.uk/.
} 
Succession Act (Cap. 146) which state that the estates are accrued to the Government. Nevertheless, based on the Public Trustee Act (Cap. 260), the Public Trustee may also undertake functions and duties related to bona vacantia in the death of natural persons, as assigned by the Minister. This concludes that bona vacantia estates are hold by the Public Trustee under the Ministry of Law.

In United Kingdom, the Administration of Estates Act 1925 provides that bona vacantia estates shall belong to the Crown. Interestingly, Companies Act 2006 also states that the properties of a dissolved company are deemed as bona vacantia. BVD under the Government Legal Department holds bona vacantia in trust, and releases it in the bona vacantia list. The general rule in United Kingdom is that the interest will be paid if the claim is made within the period of 12 years. If the estate is claimed after 12 years but up to 30 -year time limit, the interest will not be paid. However, no claim will be considered made after the 30-year period and the estate will be passed to the Crown. The comparison of the administration of bona vacantia in Malaysia, Singapore and United Kingdom are summarized in Table 1 below.

\begin{tabular}{|c|c|c|c|}
\hline Items & Malaysia & Singapore & United Kingdom \\
\hline \multirow{4}{*}{ Law } & $\begin{array}{l}\text { - Federal Constitution } \\
\text { - National Land Code } \\
1965\end{array}$ & $\begin{array}{l}\text { - Civil Law Act } \\
\text { - Civil Law (Bona Vacantia } \\
\text { Laws) Order } 2013 \\
\text { - Central Provident Fund } \\
\text { Act } \\
\text { - Child Development Co- } \\
\text { Savings Act } \\
\text { - Education Endowment } \\
\text { and Savings Schemes Act }\end{array}$ & \multirow[t]{3}{*}{$\begin{array}{l}\text { Intestate without kin } \\
\text { - Administration of } \\
\text { Estates Act } 1925 \\
\text { Dissolved company } \\
\text { - Companies Act } 2006\end{array}$} \\
\hline & \begin{tabular}{ll}
\multicolumn{1}{c}{ Muslim } \\
- & Federal Constitution \\
- & National Land Code \\
& 1965 \\
- & Small Estates \\
(Distribution) Act \\
1955
\end{tabular} & $\begin{array}{l}\text { Muslim } \\
\text { - Civil Law Act (Chapter 43) } \\
\text { - Administration of Muslim } \\
\text { Law Act (Chapter 3) }\end{array}$ & \\
\hline & \begin{tabular}{ll} 
& \multicolumn{1}{c}{ Non-Muslim } \\
- & Civil Law Act 1956 \\
- & Distribution Act 1958 \\
- & National Land Code \\
& 1965 \\
- & Federal Constitution
\end{tabular} & $\begin{array}{l}\text { Non-Muslim } \\
\text { - Civil Law Act (Chapter 43) } \\
\text { - Civil Law (Bona Vacantia } \\
\text { Laws) Order } 2013 \\
\text { - Intestate Succession Act } \\
\text { (Chapter 146) } \\
\text { - Public Trustee Act } \\
\text { (Chapter 260) }\end{array}$ & \\
\hline & Muslim: Baitulmal & Muslim: Baitulmal & $\begin{array}{l}\text { Crown } \\
\text { (BVD Legal Department) }\end{array}$ \\
\hline
\end{tabular}




\begin{tabular}{|l|l|l|l|}
\hline $\begin{array}{l}\text { Ownersh } \\
\text { ip }\end{array}$ & $\begin{array}{l}\text { Non-Muslim } \\
\text { Movable: YDPA Fund } \\
\text { Immovable: State } \\
\text { Authority }\end{array}$ & $\begin{array}{l}\text { Non-Muslim: } \\
\text { Public Trustee under } \\
\text { Ministry of Law }\end{array}$ & \\
\hline $\begin{array}{l}\text { Maximu } \\
\text { m period }\end{array}$ & $\mathrm{X}$ & $\mathrm{X}$ & $\begin{array}{l}\cdot 1-12 \text { years: With } \\
\text { interest } \\
-13-30 \text { years: Without } \\
\text { interest }\end{array}$ \\
\hline
\end{tabular}

Table 1: The comparison of the administration of bona vacantia in Malaysia, Singapore and Unied Kingdom

\section{Conclusion and Recommendations}

In conclusion, depending on the jurisdiction of each state, the administration of bona vacantia is regulated by a variety of laws and procedures. In both Malaysia and Singapore, the administration of bona vacantia is based on the deceased's religion. For Muslims, the estate is reverted to Baitulmal, whereas for non-Muslims, such estate is accrued to the Government. Conversely, in United Kingdom, the law provides that the BVD under the Government Legal Department will hold such estates up to 30 years and after this period, they shall belong to the Crown.

As mentioned earlier, in Malaysia, the existence of various laws that governs different types of unclaimed estates has led to the distinctive methods in the administration and management of such estates. This research however would establish a valid and structured findings on the governing laws of bona vacantia estates in Malaysia so that productive elements of such estates would be activated to the advantage of the rightful beneficiaries.

Apart from that, based on the comparative analysis which has been discussed above, the Malaysian authority is hope to be able to impose certain appropriate platform mechanism to regulate, manage the issues and collect the data on bona vacantia by emulating certain practiced by the United Kingdom. For instance, the authority may take advantage on interest payment for any claim made by the beneficiary up to certain years in order to encourage beneficiaries to cooperate together to claim the estates in question as soon as possible. This however, could only be done and justified once the authority introduce Unclaimed Estates Websites to ensure information accessibility and act as a platform for long lost beneficiaries or relatives to meet up virtually.

\section{Acknowledgement}

The authors fully acknowledge the sponsorship from the Universiti Teknologi MARA Cawangan Johor under Bestari Grant Scheme entitled The Administration of Bona Vacantia (Ownerless Estates) in Johor: A Socio-Legal Analysis 600-TNCPI 5/3/DDN (01) (029/2020).

\section{References}

Administration of Estates Act 1925 (United Kingdom)

Administration of Muslim Law Act (Cap. 3) (Singapore)

Al-Zuhayli, W. ibn M. (n.d). Al-Figh Al-Islami wa Adillatuh. Dimashq: Dar Al-Fikr. 
Aziz, I. H. (2016). RM60b property of muslims is not claimed. Daily News. Retrieved from http://www.bharian.com.my/node/138450

Central Provident Fund Act (Cap. 36) (Singapore)

Child Development Co-Savings Act (Cap. 38A) (Singapore)

Civil Law Act 1956 (Act 67) (Malaysia)

Civil Law Act (Cap. 43) (Singapore)

Civil Law (Bona Vacantia Laws) Order 2013 (Singapore)

Civil List Act 1910 (United Kingdom)

Companies Act 2006 (United Kingdom)

Court Funds Rules 2011 (United Kingdom)

Crown Estate Act 1961 (United Kingdom)

Distribution Act 1958 (Act 300)

Education Endowment and Savings Schemes Act (Cap. 87A) (Singapore)

Federal Constitution (Malaysia)

Gov.uk. (2020, January 14). Bona Vacantia: Meaning of 'bona vacantia'. Retrieved from https://www.gov.uk/hmrc-internal-manuals/bona-vacantia-manual/bvg1020

Gov.uk. (n.d) (a). About us. Retrieved from https://www.gov.uk/government/organisations/bona-vacantia/about

Gov.uk. (n.d)(b). What the Government Legal Department does. Retrieved from https://www.gov.uk/government/organisations/government-legal-department.

Gov.uk. (n.d)(c). The Crown Estate. Retrieved from https://www.gov.uk/gove rnment/organisations/the-crown-estate.

Gov.uk. (n.d)(d). Guidance Make a claim to a deceased person's estate. Retrieved from https://www.gov.uk/uncla imed-estates-bona-vacantia/grants-from-a-deceasedpersons-estate.

Halim, A. H., Bustami, T. A. A., Salim, W. N. M., \& Yusoff, R. M. (2019). The Administration of Muslim's and Non-Muslim's Ownerless Estate (Bona Vacantia) West Malaysia: An Analysis. International Journal of Law, Government and Communication, 4(16), 26-34.

Halim, A. H., Noor, N. A. M., Arshad, A. (2018) Administration of Unclaimed Estates in Malaysia: The Peculiarities of Unclaimed Money, Undistributed Fund and Bona Vacantia. Journal of Social Sciences Research (JSSR), 4(12): 1075-1079.

Halim, A. H., \& Yusoff, R. M. (2019), The Impacts of Non-Administered Estate in West Malaysia: An Analysis, Journal of Islamic Law Review, 15(1): 103-123.

Haniff, W. A. A. W., Hakimah, A., Ismail, R. (2019). The Regulation of Equity Crowdfunding in Malaysia and United Kingdom. Academic Journal of Interdisciplinary Studies, 8(3): 45-56.

Intestate Succession Act (Cap. 146) (Singapore).

Kuek, C. Y., \& Tay, E. S. (2013). Religious conversions and the conflicts between Civil and Islamic Law of Inheritance in Malaysia. Malayan Law Journal.

National Land Code 1965 (Act 56)

Nor, R. M. (2015). Success Factors for Baitulmal Management during the Reign of Caliph Umar ibn Abdul Aziz. Open Journal of Social Sciences, 3(05),

Public Trustee Act (Cap. 260) (Singapore)

Salim, N. M. (2012). Islamic Law of Succession: A Practical Guide to the Laws of Faraid. Malaysian Current Law Journal Sdn. Bhd.

Sihombing, J. (1981). National Land Code, A Commentary. Singapore: Malayan Law Journal Pte. Ltd. 
INTERNATIONAL JOURNAL OF ACADEMIC RESEARCH IN BUSINESS AND SOCIAL SCIENCES

Vol. 11, No. 5, 2021, E-ISSN: 2222-6990 @ 2021 HRMARS

Small Estates (Distribution) Act 1955 (Act 98) (Malaysia)

Tyabji, F. B. (1940). Muhammadan law (pp. 228-31). Bombay

Unclaimed Estates. (2021, May 21). Latest Estates 21 May 2021 from BV live. Retrieved from http://www.unclaimedestates.scot/.

Yusoff, R. M. (2019) "The Administration of Unclaimed Estates in West Malaysia: Formulating A Legal Framework," (Ph.D thesis, International Islamic University, 2019). 